\title{
Transversal Competencies for Digital Readiness and Development of Human Capital in Engineering Education
}

\author{
Anda Abuže \\ Rezekne Academy of Technologies \\ Latvia \\ anda.abuze@rta.lv
}

\author{
Velta Lubkina \\ Rezekne Academy of Technologies \\ Latvia \\ velta.lubkina@rta.lv
}

\begin{abstract}
The research is carried out within the framework of Rezekne Academy of Technology, Latvia in cooperation with West Ukrainian National University, Ukraine LV - UA project "Gender aspects of digital readiness and development of human capital in regions" Nr.LV-UA/ 2018/3.

Nowadays, educational institutions have to adapt to the new situation, make changes that would promote the transformation of the study process, promote the development of digital readiness and human capital.

The aim of the research is to study the need for transversal competencies, innovation, entrepreneurship and development of digital readiness and human capital in engineering studies. The monographic and descriptive method has been applied for studying scientific literature and modeling method for a professional development plan.
\end{abstract}

Keywords - digital readiness, engineering education, human capital, transversal competencies.

\section{INTRODUCTION}

The coronavirus (COVID-19) pandemic in all over the world places people in a new situation and it demands the need for competencies for all employees and all professions to work in specific and health-hazardous conditions. Covid-19 has changed the global economy, accelerating the transformation of higher education and improving the digital skills of staff and students.

The research is carried out within the framework of Rezekne Academy of Technologies, Latvia in cooperation with West Ukrainian National University (previously Ternopil National Economic University), Ukraine LV - UA project "Gender aspects of digital readiness and development of human capital in regions” Nr.LV-UA / 2018/3.

The study is based on research about digital readiness and gender inequality in cultural and regional terms by the project "Gender aspects of digital readiness and development of human capital in regions".

Engineering sciences are a widely represented field. In the Law on Scientific activity of Latvia is marked the field of Engineering and Technology, which includes civil and transport engineering, electrical engineering, electronics, information and communication technologies, mechanical engineering and mechanics, chemical engineering, materials engineering, medical engineering, environmental biotechnology, industrial biotechnology, nanotechnology and other engineering sciences and technologies, including food and beverage technologies [1].

Rezekne Academy of Technologies implements engineering study programmes, preparing professionals for the labor market, such as Mechatronics, Civil engineering, Engineer of programming, Environmental engineer, Laser Technologies, etc. In these programmes the main emphasis is placed on the professional study courses. However, nowadays educational institutions have to adapt to the new situation, make changes that would promote the transformation of the study process, promote the development of digital readiness and human capital. It is now obvious that the education system must not only provide theoretical and practical knowledge in a profession specific field, but also develop the social skills useful to live and work in today's changing society [2], [3].

The aim of the research is to study the need for transversal competencies, innovation, entrepreneurship and the development of digital readiness and human capital in engineering studies.

The monographic and descriptive method has been applied for studying scientific literature and modeling method for a professional development plan. 


\section{TRANSVERSAL COMPETENCIES FOR THE DEVELOPMENT OF DIGITAL READINESS AND HUMAN CAPITAL IN ENGINEERING}

The industrial revolution has been the most important in the history of human development, it has increased industrial productivity, changed economic development and created the structure of education. The paradigm shift in engineering education is closely linked to the industrial revolution (table 1 ).

During the first industrial revolution, workers had enough with basic knowledge to work with equipment. Workers did not need or have access to education, only the richest people could afford to study [4].

The second industrial revolution introduced conveyor lines, products were produced in bulk, the worker needed basic reading, writing and specific work skills on his work equipment [5].

During the third industrial revolution, digitalization took place, automated control of equipment was introduced, introduction of digital control (CNC) machine tools, development of microprocessors. During this period, the worker must be educated to be able to operate and program various equipment [6].

The fourth industrial revolution, 'Industry 4.0', brings together everything that has been known so far, creating interdisciplinary, replacing all works with digital and remote access, as well as artificial intelligence. During this time, the employee is expected to have extensive knowledge in several areas. It is no longer enough to have one narrow specialty, it is necessary to solve tasks related not only to the field itself, but also to digitization, autonomy. At this stage, unequal digital readiness and development of human capital in the regional aspects appears and it is emerging. 'Industry 4.0' is influencing production processes that are becoming increasingly complex and industry is being digitized. Smart systems need trained staff to deal with a variety of unexpected situations, changing working conditions [7], [8].

Analyzing the materials of Latvian periodicals available on the portal Periodika.lv, it can be concluded that engineering education has been relevant in the past as well. In 1935, Professor A. Tramdahs explained the responsibilities of an engineer's work, in general it is called a creative process in solving certain problems, a highquality engineer must apply several important skills "The work of an engineer begins with the understanding the problem and the solution of the resulting tasks on the basis of science, with scientific methods" [9].

In the 1982 newspaper Plèsums, assistant G. Zakis mentioned his thoughts about what an engineering specialist should be like, for example, basic knowledge in the specialty, sociability, efficiency, logical thinking, research skills and humanity [10].

TABLE 1 INDUSTRIAL REVOLUTION

\begin{tabular}{|c|c|c|c|}
\hline Title & Period & Description & Keyword \\
\hline $\begin{array}{c}\text { The 1st Industrial } \\
\text { revolution }\end{array}$ & $\begin{array}{c}\text { Middle of the 18th century - } \\
\text { middle of the 19th century } \\
(1760-1840)\end{array}$ & $\begin{array}{c}\text { Transition from manufacturing to } \\
\text { industrial production. Production } \\
\text { mechanization. }\end{array}$ & Mechanical \\
\hline $\begin{array}{c}\text { The 2nd Industrial } \\
\text { revolution }\end{array}$ & $\begin{array}{c}\text { End of the 19th century - } \\
\text { beginning of the 20th century } \\
(1870-1914)\end{array}$ & $\begin{array}{c}\text { Introduction of conveyors. Mass } \\
\text { production. }\end{array}$ & Electrical \\
\hline $\begin{array}{c}\text { The 3rd Industrial } \\
\text { revolution }\end{array}$ & $1970-2010$ & $\begin{array}{c}\text { Manual devices have been replaced by } \\
\text { CNC machines. Automated production. }\end{array}$ & $\begin{array}{c}\text { Complete computerization, } \\
\text { interconnection of mechanisms, } \\
\text { interdisciplinary, artificial intelligence. }\end{array}$ \\
\hline $\begin{array}{c}\text { The 4th Industrial } \\
\text { revolution }\end{array}$ & $2010-$ present & & Internet of Things \\
\hline
\end{tabular}

\section{PROFESSIONAL DEVELOPMENT PLAN FOR ENGINEERING STUDENTS FOR THE DEVELOPMENT OF DIGITAL READINESS AND HUMAN CAPITAL}

Boston Consulting Group (BGC) has identified nine technology trends as key elements of Industry 4.0 (Figure 1). Equal quality, digital readiness and gender equality must be ensured in the education process in all regions.

It is important to connect the education system to industrial changes, to adapt to the latest trends. Engineers also need training in the latest technologies related to the field of information technology - Internet of Things, cybersecurity, cloud services, virtual reality, big data and analytics, autonomous robots, simulations.

In education, it is important to think interdisciplinary, to use different methods to achieve the goal. Research indicates that engineering education must be flexible, constantly updating and adapting to the latest technologies [11]. 
Environment. Technology. Resources. Rezekne, Latvia Proceedings of the $13^{\text {th }}$ International Scientific and Practical Conference. Volume 2, 220-224

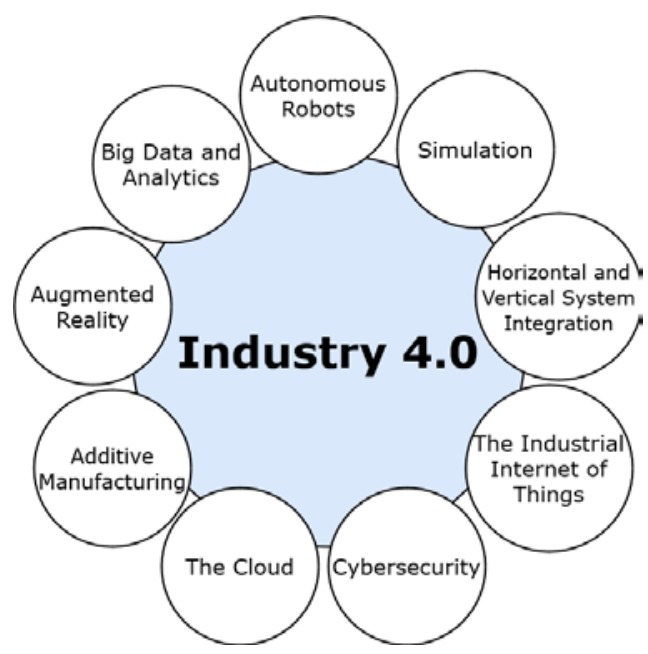

Leandro Cruz \& Saunders-Smith (2019) conducted a research to determine the level of competencies of bachelor's and master's degree graduates based on the industry's understanding of competencies. This research highlighted entrepreneurship, innovation, communication, teamwork and lifelong learning competencies [13], [14].

The project of University of Latvia “Assessment of the Students' Competences in Higher Education and their Development Dynamics during Study Period” ESF 8.3.6.2. "Development of Education Quality Monitoring System” 8.3.6.2/17/I/001 (23-12.3e/19/103) has created an entrepreneurship, innovation and digital competence structure (Figure 2).

Fig. 1. Industry 4.0 key technologies [12]

\section{Innovation competence

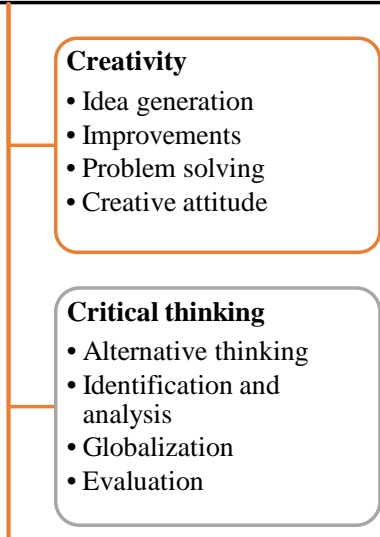

\section{Initiative}

- Encourages other action

- Mobilization

- Organization of work

implementation

- Implementation of ideas

- Risk-taking initiatives

- Active involvement and independence

\section{Team work}

- Cooperation skills

- Improving teamwork

\section{Networking}

- Internal networking

- External networking

\section{Entrepreneurship competence}

Problem solving and creativity

- Ability to notice opportunities

- Creativity

- Vision

- Ability to evaluate ideas

- Ethical and sustainable thinking

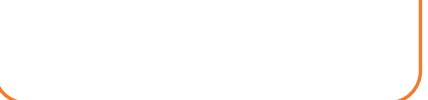

Ability to identify, mobilize and effectively use internal and external resources

- Awareness of skills and selfeffectiveness

- Motivation and perseverance

- Financial and economic

competence

- Ability to mobilize and motivate

human resources

Action orientation, initiative and ability to overcome obstacles, solve problem situations and create new value

- Taking the initiative

- Planning and management

- Ability to deal with uncertainty

and risk

- Team work

- Learning from experience

\section{Digital competence}

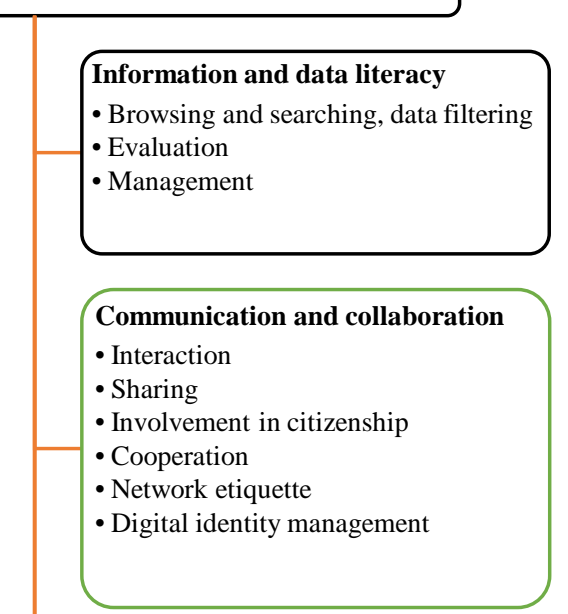

Digital content creation

- Development

- Integration

- Copyright and licenses

- Programming

\section{Safety}

- Device protection

- Protection of personal data and privacy

- Protection of health and welfare

- Environment protection

\section{Problem solving}

- Solving technical problems

- Needs assessment and technological solutions

- Creative use of digital technologies

- Identifying digital skills gaps 
Analyzing the scientific literature, different ways of learning transversal competencies are described, for example, problem-based learning, project-based learning, games, simulations, discussions [16], [17], [18], [2].

Following the theoretical module of O. Mikhailenko, T. Blayone, I. Žogla, V. Lubkina has been developed a professional development plan, which improves digital, entrepreneurship and innovation skills of Mechatronics students in the study course "Sensor data processing" (Figure 3) [19].

In the successful interaction of all components, students' skills are improved in several areas, as well as digital readiness is developed. Transversal competencies are increasingly being recognized by engineers because work becomes increasingly interdisciplinary. According to the research by S. Coşkun, Y. Kayıkcı, E. Gençay, the integration of 'Industry 4.0' in engineering education requires 3 basic stages - a curriculum, laboratories and a student club, where students have the opportunity to design, present and further develop their projects [20].

In order to fully master the course, theoretical lectures are required, where the basics of the topics corresponding to the course, guest lectures by industry experts or, for example, video tours in companies are provided. In the study process must be provided skills for the development of innovative, entrepreneurship and digital competence. This process also requires practical classes, such as laboratory work, where theoretical knowledge and digital and innovative competence must be applied. Individual work will be presented using entrepreneurship competence.

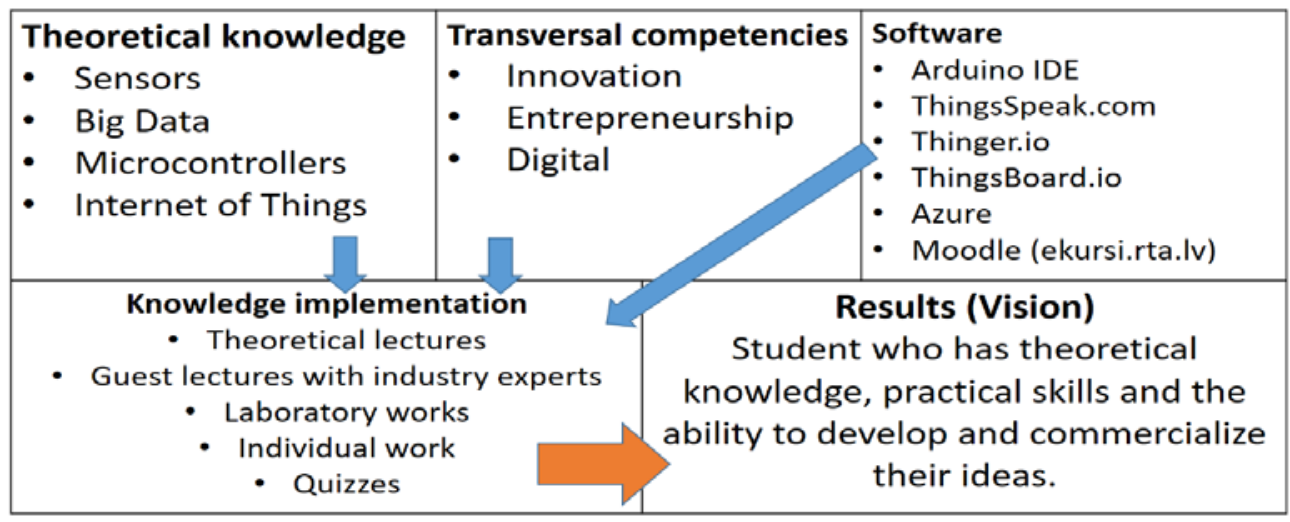

Fig. 3. Professional development plan

\section{CONCLUSION}

The education system is not suitable for nowadays life. The education system must not only provide theoretical and practical knowledge in a profession specific field, but also prepare students for the digital environment, gender equality and the social skills needed to live and work in today's changing society.

Getting acquainted with historical sources in Latvia, it can be concluded that engineering education has been important in the past, as well as it has been significantly influenced by the Industrial Revolutions. We are currently in the Industry 4.0 processes, which affects the production process, it is becoming increasingly complex and the work is interdisciplinary. Technological changes are especially important for future engineers, who will have to work in this period of change.

Within the framework of the research, the professional development plan has been developed, which will be used as a basis for the improvement of the course "Sensor data processing". It provides an example of how to acquire the study course by combining it with transversal competencies using digital tools and various teaching methods. This will improve students' digital, entrepreneurship and innovation competences.

\section{ACKNOWLEDGMENTS}

This article was supported by the Latvia - Ukraine Joint Cooperation programme project "Gender aspects of digital readiness and development of human capital in regions” Project Nr.LV-UA/2020/4.

\section{REFERENCES}

[1] Ministru kabinets, "Noteikumi par Latvijas zinātnes nozarēm un apakšnozarēm," Ministru kabineta noteikumi Nr. 49, 2018. https://ikumi.lv/ta/id/296661-noteikumi-par-latvijas-zinatnesnozarem-un-apaksnozarem.

[2] M. Sá and S. Serpa, “Transversal Competences: Their Importance and Learning Processes by Higher Education Students,” Education Sciences, vol. 8, no. 3, p. 126, Aug. 2018, doi: 10.3390/educsci8030126.

[3] M. Woschank and C. Pacher, "Program Planning in the Context of Industrial Logistics Engineering Education,” Procedia Manufacturing, vol. 51, pp. 1819-1824, 2020, doi: https://doi.org/10.1016/j.promfg.2020.10.253.

[4] A. Trew, "Spatial takeoff in the first industrial revolution," Review of Economic Dynamics, vol. 17, no. 4, pp. 707-725, 2014, doi: https://doi.org/10.1016/j.red.2014.01.002. 
[5] H. Mohajan, "The Second Industrial Revolution has Brought Modern Social and Economic Developments,” Journal of Social Sciences and Humanities, Vol. 6, No. 1, pp. 1-14, 2020, [Online]. Available: https://mpra.ub.uni-muenchen.de/98209/.

[6] J. Rymarczyk, "Technologies, Opportunities and Challenges of the Industrial Revolution 4.0: Theoretical Considerations," Entrepreneurial Business and Economics Review, vol. 8, no. 1 SEArticles, Mar. 2020, doi: 10.15678/EBER.2020.080110.

[7] A. Benešová and J. Tupa, "Requirements for Education and Qualification of People in Industry 4.0,” Procedia Manufacturing, vol. 11, pp. 2195-2202, 2017, doi: https://doi.org/10.1016/j.promfg.2017.07.366.

[8] N. Carvalho, O. Chaim, E. Cazarini, and M. Gerolamo, "Manufacturing in the fourth industrial revolution: A positive prospect in Sustainable Manufacturing," Procedia Manufacturing, vol. 21, pp. 671-678, 2018, doi: https://doi.org/10.1016/j.promfg.2018.02.170.

[9] A. Tramdahs, “Inženieru darbs,” Students, no. 218. 1935, [Online]. Available: $\quad$ http://periodika.lv/periodika2-viewer/view/indexdev.html?lang=fr\#panel:pa\%7Cissue:/p 001 stud1935n218\%7Car ticle:DIVL55\%7CissueType:P.

[10] G. Zaḳis, "INŽENIERA PAMATPIENĀKUMS," Plēsums, no. 18, Dec. 1982, [Online]. Available: http://periodika.lv/periodika2viewer/view/indexdev.html?lang=fr\#panel:pa\%7Cissue:/p_001_ples1982n18\%7Carti cle:DIVL135\%7Cquery:prasme Prasme\%7CissueType:P.

[11] G. Marzano, A. Martinovs, and S. Ušča, "MECHATRONICS EDUCATION: NEEDS AND CHALLENGES,” Environment. Technology. Resources. Proceedings of the 12th International Scientific and Practical Conference. Volume 2, 2019, doi: 10.17770/etr2019vol2.4199.

[12] "Embracing Industry 4.0 and Rediscovering Growth," Boston Consulting Group, https://www.bcg.com/capabilities/operations/embracing-industry4.0-rediscovering-growth.aspx (accessed Jan. 09, 2020).

[13] M. Leandro Cruz and G. Saunders-Smits, "Transversal Competency Level of Engineering Graduates Dictated by European Industry,” 2019, [Online]. Available: http://resolver.tudelft.nl/uuid:88bd1e06b898-4948-aa28-b56d5b8ab60f.

[14] M. L. Cruz, G. N. Saunders-Smits, and P. Groen, "Evaluation of competency methods in engineering education: a systematic review,” European Journal of Engineering Education, vol. 45, no. 5, pp. 1-29, 2019, doi: 10.1080/03043797.2019.1671810.

[15] "University of Latvia project “Assessment of the Students' Competences in Higher Education and their Development Dynamics during Study Period” ESF 8.3.6.2. 'Development of Education Quality Monitoring System’ 8.3.6.2/17/I/001 (2312.3e/19/103).”

[16] M. Caeiro-Rodríguez et al., "Teaching Soft Skills in Engineering Education: An European Perspective," IEEE Access, vol. 9, pp. 29222-29242, 2021, doi: 10.1109/ACCESS.2021.3059516.

[17] J. Bezerra et al., "Developing Transversal Competences in Engineers,” 2018.

[18] J. Stal and G. Paliwoda-Pękosz, "Fostering development of soft skills in ICT curricula: a case of a transition economy," Information Technology for Development, vol. 25, no. 2, pp. 250-274, Apr. 2019, doi: 10.1080/02681102.2018.1454879.

[19] O. Mykhailenko, T. Blayone, I. Žogla, and V. Lubkina, "USING ACTIVITY THEORY FOR MODELLING TRANSFORMATIVE DIGITAL LEARNING,” ENVIRONMENT. TECHNOLOGIES. RESOURCES. Proceedings of the International Scientific and Practical Conference, vol. 2, p. 222, Jun. 2019, doi: 10.17770/etr2019vol2.4044.

[20] S. Coşkun, Y. Kayıkcı, and E. Gençay, "Adapting Engineering Education to Industry 4.0 Vision,” Technologies , vol. 7, no. 1. 2019, doi: $\underline{10.3390 / \text { technologies7010010. }}$. 